ISSN: 1838-3815 (online) Journal Homepage: https://ojs.deakin.edu.au/index.php/itlge/

\title{
Joining up the dots: Telling the story of employability. How can students in Higher Education be supported to better understand and articulate their employability?
}

\author{
Gail de Blaquière ${ }^{1}$, Jane Elizabeth Nolan ${ }^{1}$ and Katie Wray ${ }^{1}$ \\ Corresponding author: Jane Nolan (jane.nolan@ncl.ac.uk) \\ ${ }^{1}$ Newcastle University, UK
}

\begin{abstract}
Employability is a complex, contested concept which has tended to be considered in terms of a dominant discourse of skills. This article argues that employability needs to be thought of more holistically, as ongoing, life-long, situated learning, whilst acknowledging that the contested language of skills and the need to demonstrate competency through examples is embedded in employers' recruitment processes. Therefore the ability to articulate what a graduate can offer to employers, framed in terms of skills and expressed in narratives which provide convincing examples, is important in establishing potential employability. Research shows that undergraduate and postgraduate students can find this problematic. In addition, recent scholarship calls for research to create a theoretically informed understanding of why and how interventions aimed at enhancing employability are effective. The authors have researched a diverse range of interventions which have had a positive impact and which are based on the principles of enterprise education and experiential learning. Their findings, based on qualitative and quantitative data collected from participants, suggest that experiential learning can be helpful in enabling students to more confidently articulate their employability by providing examples of skilful practices applied in context. It is unusual for undergraduate (UG) and post graduate (PG) student learning experiences to be considered within the same research project however, the correlation of results and outcomes provides valuable points of reflection. The interventions explored provide examples of ways in which a practice architecture based on experiential learning can support understanding, confidence, metacognition and the creation of narratives, enhancing students' capacity to 'join up the dots', and tell the story of their employability.
\end{abstract}

Keywords:

skills, experiential learning, practice architecture, enterprise education, metacognition, narratives of employability

\section{Introduction}

The focus of this study is on particular types of intervention used in programmes, schools and modules which have a demonstrable positive impact on participants' perceptions of their 
employability skills. Evidence of this was provided through project outcomes and reported through feedback. The interventions, which will be detailed later, were varied: co-curricular, extra-curricular and within the curriculum; yet the observations were consistent. They involved students at different levels of study, from undergraduates to taught post-graduates, post-graduate and early career researchers. All interventions were intended to enhance individuals' employability within academia and beyond, and all were based on the pedagogies of experiential learning and enterprise education. Whilst research and reports (Bryant, 2005; HEA, 2015; Knight \& Yorke, 2004; Nolan, 2018) suggest that students can find it difficult to perceive and articulate their employability skills, many participants taking part in the interventions seemed to be able to create narratives which helped to evidence their employability, drawing on examples from their experiences during the programmes, schools and modules under consideration. This raised the questions of why and how this was the case.

The inter-disciplinary team who participated in the project have backgrounds in the arts, humanities, engineering and sciences and have adopted research methods which help to validate the data from different epistemological perspectives. The literature and scholarship of employability, experiential learning and enterprise education has been used to theoretically inform, analyse and interpret data and practice. In this study, employability has been approached as a complex and contested concept, which needs to be seen holistically, as life-long, ongoing, situated learning (Harvey, 2000; Knight \& Yorke, 2004; Wenger, 1998; Yorke, 2006). The authors have recognised that whilst the discourse of skills is dominant, there is no shared language of skills and its meaning is unclear (Holmes, 2013, 2015; Knight \& Yorke, 2004). Despite this, the contested language of skills is embedded in employers' recruitment practices and the ability to articulate what a graduate can offer to an employer, framed in terms of skills and expressed in narratives which provide convincing examples, is important in establishing potential employability. Recent literature in the employability field has suggested that it is important to implement potential employability-related interventions on the basis of research, evidence and theory, to provide an understanding of how they work and identify the elements which make them effective, rather than simply doing what seems to work (Holmes, 2017).

\section{Aims}

This research project is based on the analyses made by the authors as members of academic staff of extensive data gathered from participants over a number of years, with the aim of gaining a deeper understanding of the outcomes of their practice, as outlined in the introductory paragraph, and to theorise why their interventions performed as they did. The paper seeks to:

1) Understand how and why participants engaging in employability-related interventions that are experiential and informed by enterprise education seem to gain valuable insights into what they can offer an employer and create narratives to evidence their potential employability.

2) Map participants' reported skills outcomes to the USEM (Understanding, Skilful Practice, Efficacy Beliefs, Metacognition) model of employability (Knight \& Yorke, 2004) in order to investigate whether experiential learning opportunities enable participants to apply skilful practices in context; gain efficacy and confidence through transformative, action based learning; achieve metacognition and self-awareness through reflection, and thus enable convincing, validated claims about their employability to be made.

3) Explore the impacts of working across the boundaries of disciplines, academia, communities and business, including the challenges of responding to new and more uncertain learning situations and how this contributes to developing new narratives and constructions of

de Blaquière , G.E., Nolan, J.E., \& Wray, K. (2019). Joining up the dots: telling the story of employability. How can students in Higher Education be supported to better understand and articulate their employability? Journal of Teaching and Learning for Graduate Employability, 10(2), 15-35. 
participant identity (Akkerman \& Bakker, 2011) which contribute to their understanding of their employability.

4) Create an architecture of practice, a framework which might be adopted by others in order to design interventions and which could create the basis for further practitioner research.

\section{Context of the study}

The extensive academic literature on employability provides evidence that it is a contested and controversial topic. Policy approaches are largely based on Human Capital and Rational Action theories (Becker, 1975), which neglect crucial aspects of what has been evidenced to be a highly complex and multi-dimensional construct. Research has shown that employability in a neoliberal age can overemphasize the agency of individuals, although many factors impinge on the ability to gain employment. They include the availability of graduate jobs in the labour market, the impact of social class, gender, ethnicity, both in terms of their effect on the perceptions and horizons of individuals and the recruitment practices of employers, the capacity of individuals to create the social and cultural capitals which can enhance the degree credential, and the reputational capital associated with the university attended (Bathmaker, Ingram, \& Waller, 2013; Brown, Hesketh, \& Williams, 2004; Mok \& Wu, 2016; Morley, 2007; Reay, 1998, 2013; Tomlinson, 2007). Furthermore, employability is conceptualised in terms of a dominant, but equally contested and imprecise language of skills (Holmes, 2013, 2015; Knight \& Yorke, 2004). Against this complex backdrop, it is argued that the provision of effective interventions which support participants in developing, understanding, reflecting on and articulating their employability can help individual prospects.

\section{Principles of the study}

This study maps employability interventions to the four inter-related components of the USEM model (Knight \& Yorke, 2004). USEM has been selected because the model offers a way of considering employability as a holistic set of interrelated conceptual ideas which moves beyond the dominant discourse of skills, an approach which the authors consider appropriate to this complex topic. It moves beyond the discourse of skills to suggest that a blend of Understanding, Skilful practices, Efficacy beliefs and Metacognition contribute to developing, understanding, reflecting on and articulating employability.

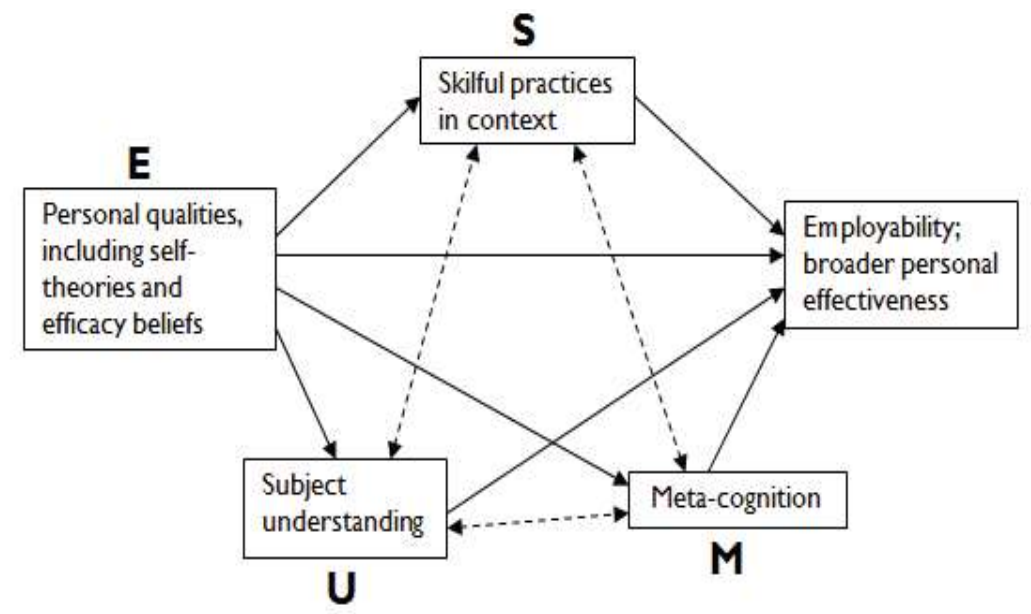

Figure 1: USEM Model of Employability (The Higher Education Academy, 2013)

As Knight and Yorke have argued, the concept and language of skills, including hard, soft and transferable skills, lacks clarity and has significant shortcomings, since skills are not objects but are related to the person, to situated practice and to performance in context (Knight \& Yorke, 2004, pp.

de Blaquière , G.E., Nolan, J.E., \& Wray, K. (2019). Joining up the dots: telling the story of employability. How can students in Higher Education be supported to better understand and articulate their employability? Journal of Teaching and Learning for Graduate Employability, 10(2), 15-35. 
32-33). The discourse of skills generally lacks this consideration of practice and performance. The use of skilful practice in the USEM model addresses this and situates skills in context. Therefore in this study the terms hard, soft and transferable in relation to skills have not been used to try to distinguish between different kinds of skills. Instead the term employability skills is used; they are developed and understood through skilful practices as part of an ongoing, situated process of learning throughout life, study and employment.

Since the interventions considered in this study (see Table 1) were aimed at enabling participants to develop their employability through applying skills in context, a number of areas of skilful practice and efficacy beliefs were identified as significant. Questions relating to progress against these key areas of skilful practice and efficacy belief have been used in the analysis. They included: selfawareness; self-confidence; communication; creativity; entrepreneurialism and commercial awareness/viability; and group/teamwork. These aspects of employability are also present in significant reports and frameworks and are thus seen as important to a range of stakeholders: the ESECT team's 39 aspects of employability, a heuristic created for the Skills-plus Project to guide the evaluation of curricula (Knight \& Yorke, 2004); the Universities UK and CBI Future Fit report considering graduate employability skills and employers' requirements (Universities UK \& CBI); the VITAE Researcher Development Framework (Reeves, Denicolo, Metcalfe, \& Roberts, 2012).

The principles of enterprise education, which are a key component of this study, are defined by David Rae (2007: p. 611) as 'the skills, knowledge and attributes needed to apply creative ideas and innovations to practical situations'. Recently, enterprise education has been defined by expert contributors, brought together to update the QAA Benchmark Guidelines for Enterprise and Entrepreneurship (QAA, 2018) as:

The application of creative ideas and innovations to practical situations. This is a generic concept that can be applied across all areas of education. It combines creativity, ideas development and problem solving with expression, communication and practical action. This definition is distinct from the generic use of the word in reference to a project or business venture. Enterprise education aims to produce graduates with the mind-set and skills to come up with original ideas in response to identified needs and shortfalls, and the ability to act on them. In short, having an idea and making it happen. Enterprise skills include taking the initiative, intuitive decision making, making things happen, networking, identifying opportunities, creative problem solving, innovating, strategic thinking, and personal effectiveness. Enterprise education extends beyond knowledge acquisition to a wide range of emotional, intellectual, social, and practical skills (QAA, 2018, p. 7).

Enterprise education can enhance careers education and student employability by enabling participants to be more opportunity-focussed, self-aware and attuned to the business environment (QAA, 2018). The interventions under consideration have also used experiential learning as a foundational enterprise education pedagogy. Using a popular definition from Simon Fraser University (Simon Fraser University, 2012), experiential learning is 'the strategic, active engagement of students in opportunities to learn through doing, and reflection on those activities, which empowers them to apply their theoretical knowledge to practical endeavours in a multitude of settings inside and outside of the classroom.' In short, students practice skills in context. In a subsequent section, the pedagogical approaches used in the interventions are discussed in more detail.

Metacognition is defined as an awareness of what one knows and how one learns more (Knight \& Yorke, 2004; Marzano, 1998). Though metacognition can be seen as a 'fuzzy concept' (Hacker, Dunlosky, \& Graesser, 1998) Rogers has provided a useful analysis of its main dimensions, encompassing learning how to learn, confidence in the capability to learn and that the experience of learning can be meaningful beyond didacticism, to be transformative, changing the student's conception of herself and her view of the world (Rogers, 1969). It is argued that the metacognitive

de Blaquière , G.E., Nolan, J.E., \& Wray, K. (2019). Joining up the dots: telling the story of employability. How can students in Higher Education be supported to better understand and articulate their employability? Journal of Teaching and Learning for Graduate Employability, 10(2), 15-35. 
dimension of the USEM model is essential to draw together experiences through effective reflective practice in order to better understand potential employability. This is especially significant given acknowledgement in the literature of the benefits and challenges of modular degree structures, which may tend to fragment the educational experience, rather than enabling students to connect different aspects of their learning (French, 2015). Ongoing doctoral research suggests that this metacognitive level of learning, which it is argued is crucial to understanding and articulating employability skills, may be proving harder to achieve within the episodic nature of learning in modular degree structures (Nolan, 2018).

Narratives are seen as significant in articulating employability to potential employers. The USEM model emphasises that evidencing employability involves making convincing claims under each of the four dimensions (Knight \& Yorke, 2004, p. 7). Holmes $(2013,2015)$ has argued the formation of a graduate identity which can be validated within the workplace through performance of skills, is significant in becoming employable. Narratives of employability are defined in this study as the articulation of skilful practices which demonstrate competent performance of skills in context, thus storying employability and supporting the development of a sense of identity as an employable graduate who perceives what she can offer to an employer expressed in terms an employer will understand. Furthermore, narratives are fundamental to identity construction (Lawler, 2002, 2014), to understanding how individual experiences cohere as part of a whole and the way that we understand ourselves and the world (Polkinghorne, 1988). Graduates need to be able to develop coherent narratives which are grounded in an understanding of their employability and to articulate this effectively in order to validate their identity as graduates and have the best chances for their futures after graduation.

In addition, when graduates move from their university careers into the world of work, they cross socio-cultural boundaries, which create discontinuities, in which they need to learn about changes in rules, context, language and expectations (Akkerman \& Bakker, 2011). Vertical learning is required to gain the specific knowledge for a role and workplace, but in addition horizontal learning, that is the learning across domains, for example from the graduates' discipline, extra-curricular experience, work experience and wider social and cultural worlds, is also needed to support the transition (Akkerman \& Bakker, 2011). The interventions under consideration in this article use real life issues and offer the opportunity to work across the boundaries of disciplines, of academia, business and community, to enable participants to apply and reflect on their knowledge, skills and confidence and their application in a range of contexts, thus making them meaningful in terms of daily lives and concerns and expanding traditional notions of learning beyond single domains (Akkerman \& Van Eijck, 2013).

\section{Research methodology}

The authors collected data from participants in a number of interventions, a series of modules and programmes at a Russell Group university and an international school. Details of the enterprise programme, modules, PGR development school and business start-up accelerator project under consideration, and the data collected, are provided in Table 1. All the interventions were aimed at enhancing employability through experiential learning and took place over a period of six years (2010-2016). The sources of data were both quantitative (skills perception inventories, questionnaires) and qualitative (reflective activity, module feedback, feedback forms). The data gathered in each case included questions about skills and competency outcomes (see Figures 2-5 for the specific questions). In some cases both pre- and post-programme data was collected (enterprise programme, PGR development school and business start-up accelerator project) and compared. Participants were asked a series of questions using variations of the Skills Inventory Perception (SKIPI) method (Alpay \& Walsh, 2008). Additional data was collected five months after the PGR development school to identify longer term outcomes. All participants across all the interventions

de Blaquière , G.E., Nolan, J.E., \& Wray, K. (2019). Joining up the dots: telling the story of employability. How can students in Higher Education be supported to better understand and articulate their employability? Journal of Teaching and Learning for Graduate Employability, 10(2), 15-35. 
were invited to contribute to the data. University ethical approval was obtained, and data has been used with the agreement of the participants and has been anonymised.

The original intention was to evaluate the effectiveness of each individual learning and teaching intervention as perceived by the participants. However, as has been outlined in the introduction, the apparent effectiveness of these interventions, as evidenced by the testimony of the participants, led the authors to another phase of analysis. Baseline data for comparison has been drawn from a quantitative analysis of a postgraduate researcher development workshop series, which includes experiential and non-experiential educational and training activities, and which has been consistently evaluated using Vitae's Researcher Development Framework (Reeves et al., 2012) over five years (2010-2015). The postgraduate researcher development workshops cover all four domains of the Vitae Researcher Development framework which is well-embedded and accepted within researcher development programmes nationally and internationally: Knowledge and Intellectual Abilities, Personal Effectiveness, Research Governance and Organisation and Engagement, Influence and Impact. These workshops were of differing structures and length but none were longer than two days. This data gives a comparison between active experiential learning and lecture-based or knowledge-centred non-experiential activities.

Although each of the experiential interventions(enterprise programme, PGR development school and business start-up accelerator project) were different in terms of duration, chronology and participant stage of study, analysis using the theory of practice architectures (Akkerman \& Bakker, 2011; Kemmis \& McTaggart, 1982) has established that the underlying architecture is similar. Each takes a real world problem, issue or project and asks the participants to learn actively, experientially and, at varying levels, reflectively. Each intervention involves providing an appropriately supportive learning environment, knowledge for addressing the task, establishing trust and enabling people to step out of their comfort zones to learn actively and experientially.

The scope of the study was broadened to look at activities undertaken by undergraduate students (UG), postgraduate taught students (PGT), postgraduate research students (PGR), graduates and staff researchers in both curricular and extra-curricular interventions with the intention of testing these against the baseline findings. In addition to the similarity in architecture of these interventions, all of them have an overarching practice of enterprise education (as previously defined), which is informed by the theory and practice of experiential learning. The difference in maturity between postgraduate and undergraduate students is acknowledged, however the data from each group provides valuable points of reflection.

'Confidence' and 'skills awareness' were identified as the two key dimensions, based on the hypothesis that experiential learning interventions, during which participants practice skills in context, increase a sense of self-efficacy and enable participants to achieve metacognition of their skills through effective reflective practice. These key dimensions of confidence and skills awareness (see Figures 2-5 for the detailed questions selected as representative of these two dimensions) were mapped to the 'Efficacy Beliefs' and 'Skilful Practices' aspects of the USEM model (Knight \& Yorke, 2004). A Likert scale was used to score participants' attitudes to the questions on their efficacy beliefs and skilful practice. Parametric statistical analysis was carried out on the responses (see Figures 2-5). The capacity for articulation of their skills through the provision of examples in the form of narratives was analysed as a potential indicator of whether metacognition had been achieved by individual participants.

A strength of this methodology is its use of different epistemological approaches, both quantitative and qualitative, to establish a robust body of data whilst also coming to a deeper understanding from the perspective of the participants themselves (Bryman, 2008; Cresswell, 2014; Yin, 2003). The study is replicable by ensuring that both pre- and post- programme data is gathered and compared. This should include the opportunity for discursive feedback from participants and where possible a follow up five to six months later should be made.

de Blaquière , G.E., Nolan, J.E., \& Wray, K. (2019). Joining up the dots: telling the story of employability. How can students in Higher Education be supported to better understand and articulate their employability? Journal of Teaching and Learning for Graduate Employability, 10(2), 15-35. 
Table 1: Interventions Analysed in this Study

\begin{tabular}{|c|c|c|c|c|}
\hline Intervention & Duration & Participants & Aims and Approaches & Comparison Data \\
\hline $\begin{array}{l}\text { PGR development } \\
\text { workshops } \\
\text { (single institution) } \\
\text { (extra-curricular) } \\
\text { Figure } 2\end{array}$ & $\begin{array}{l}\text { Annual } \\
\text { series }\end{array}$ & PGR students & $\begin{array}{l}\text { Aimed at developing the skills and experience UK Research } \\
\text { Councils expect researchers to have, across the } 4 \text { domains and } \\
12 \text { sub-domains of the Researcher Development Framework } \\
\text { (Reeves et al., 2012). } \\
\text { Delivery: Generally workshop-based but includes lecture based } \\
\text { sessions and technical training. Experiential options may be } \\
\text { with or without reflective elements. } \\
\text { Efficacy Belief question: This course has increased my } \\
\text { knowledge and/or improved my skills in the relevant RDF sub- } \\
\text { domains } \\
\text { Skilful Practice Question: The skills learned will improve my } \\
\text { transferable/employment skills. }\end{array}$ & $\begin{array}{l}77 \text { workshops which did not include any } \\
\text { experiential element are compared with } 87 \\
\text { workshops which had an experiential } \\
\text { element (see figure } 2 \text { ). } \\
\text { Number of participants: c } 3700 \text { attendees } \\
\text { across the whole programme with an } \\
\text { average } 60 \% \text { feedback per workshop }\end{array}$ \\
\hline $\begin{array}{l}\text { Enterprise programme } \\
\text { (single institution) } \\
\text { (extra-curricular) } \\
\text { Figure } 3\end{array}$ & 9 months & $\begin{array}{l}\text { Postgraduate } \\
\text { research students } \\
\text { and Early-Career } \\
\text { Researchers }\end{array}$ & $\begin{array}{l}\text { Aimed at enabling participants to develop their entrepreneurial } \\
\text { skills and develop inter-disciplinary solutions to real societal } \\
\text { challenges. } \\
\text { Delivery: Workshop-based, interactive; participants engage in } \\
\text { learning through developing their solution as a business } \\
\text { concept; fully experiential with reflection. } \\
\text { The questions in the SKIPI were designed to gauge confidence } \\
\text { levels in three skills areas covered in the enterprise programme } \\
\text { (Communication, Group work, Creativity and Entrepreneurial } \\
\text { skills/ commercial). } \\
\text { Researchers were asked to rate their level of confidence with a } \\
\text { series of situations or issues. A four point scale was used to } \\
\text { score participants' perceptions (with a score of } 1 \text { for very } \\
\text { uncomfortable to } 4 \text { representing very comfortable). } \\
\text { Efficacy Belief questions: Communication and Group work }\end{array}$ & $\begin{array}{l}\text { Control group: Skills Inventory Perception } \\
\text { method (SKIPI) responses from PGRs/ECRs } \\
\text { who did not participate in the programme. } \\
\text { These were not significantly different to the } \\
\text { pre-workshop responses. } \\
\text { Sample size ( } n=21 \text { pre-workshop and } n=17 \\
\text { post-workshop). } \\
\text { Number of participants: } 23\end{array}$ \\
\hline
\end{tabular}

de Blaquière, G.E., Nolan, J.E., \& Wray, K. (2019). Joining up the dots: telling the story of employability. How can students in Higher Education be supported to better understand and articulate their employability? Journal of Teaching and Learning for Graduate Employability, 10(2), 15-35. 


\begin{tabular}{|c|c|c|c|c|}
\hline & & & Skilful Practice questions: Creativity and Entrepreneurial Skills & \\
\hline $\begin{array}{l}\text { PGR Development } \\
\text { School } \\
\text { (across } 11 \text { institutions) } \\
\text { (extra-curricular) } \\
\text { Figure } 4\end{array}$ & 6 months & $\begin{array}{l}\text { Postgraduate } \\
\text { research students } \\
\text { and Early-Career } \\
\text { Researchers from } \\
6 \text { UK and } 5 \\
\text { overseas } \\
\text { Universities }\end{array}$ & $\begin{array}{l}\text { Aimed at developing future research leaders with the skills to } \\
\text { lead collaborations between different disciplines and cultures } \\
\text { including academia and business. } \\
\text { Delivery: Workshop-based interactive, } 2 \text { intensive } 2 \text { week } \\
\text { schools and } 5 \text { months team working remotely in between; } \\
\text { participants developed solutions to issues identified in } \\
\text { response to real societal challenges working in inter- } \\
\text { disciplinary teams; fully experiential with reflection. } \\
\text { Efficacy beliefs question: How confident do you feel you can } \\
\text { effectively communicate with people in different organisations? } \\
\text { Efficacy beliefs question: Confidence in developing collaborative } \\
\text { relationships } \\
\text { Skilful practice question: How confident do you feel in taking } \\
\text { creative and innovative approaches to your work? }\end{array}$ & $\begin{array}{l}\text { A Skills Perception Inventory (SKIPI) was } \\
\text { carried out prior to the first two week } \\
\text { School and just after the second two week } \\
\text { School had concluded } 6 \text { months later. } \\
\text { Further qualitative data gathered } 5 \text { months } \\
\text { after the end of the whole programme to } \\
\text { assess ongoing impact. } \\
\text { Sample size ( } n=22 \text { pre-workshop and } n=20 \\
\text { post-workshop). } \\
\text { Number of participants: } 22\end{array}$ \\
\hline $\begin{array}{l}\text { Modules } \\
\text { (single institution) } \\
\text { (curricular) }\end{array}$ & 3-9 months & Undergraduate & $\begin{array}{l}\text { Aimed at embedding the development of knowledge and skills } \\
\text { in appropriate curricula within a School including Skilful } \\
\text { practice: effective team working } \\
\text { Efficacy beliefs: confidence, self-awareness, entrepreneurial } \\
\text { skills including commercial awareness. }\end{array}$ & $\begin{array}{l}\text { Ethnographic research data including } \\
\text { interviews with students who have not } \\
\text { engaged with these modules showing lack of } \\
\text { coherent narratives about skills and } \\
\text { employability. }\end{array}$ \\
\hline
\end{tabular}

de Blaquière , G.E., Nolan, J.E., \& Wray, K. (2019). Joining up the dots: telling the story of employability. How can students in Higher Education be supported to better understand and articulate their employability? Journal of Teaching and Learning for Graduate Employability, 10(2), 15-35. 


\begin{tabular}{|l|l|l|l|l|}
\hline & & $\begin{array}{l}\text { Delivery: Blended learning, experiential and reflective } \\
\text { activities. E.g. UG student teams develop event concepts, put } \\
\text { on events for the public and reflect on the learning, skills and } \\
\text { experience applied. }\end{array}$ & $\begin{array}{l}\text { Number of participants: } 127 \text { over 4 years; } \\
\text { responses and feedback gathered: } 91\end{array}$ \\
\hline $\begin{array}{l}\text { Modules } \\
\text { (single institution) } \\
\text { (curricular) }\end{array}$ & $3-9$ months & $\begin{array}{l}\text { Postgraduate } \\
\text { Taught }\end{array}$ & $\begin{array}{l}\text { Aimed at embedding the development of knowledge and skills } \\
\text { in appropriate curricula within Schools including Skilful } \\
\text { practice: effective team working } \\
\text { Efficacy beliefs: confidence, self-awareness, entrepreneurial } \\
\text { skills including commercial awareness } \\
\text { Delivery: Blended learning, experiential and reflective activities } \\
\text { e.g. Developing a business proposal for a new idea through 2 } \\
\text { intensive teaching weeks and independent working. }\end{array}$ & $\begin{array}{l}\text { Qualitative data taken from open questions } \\
\text { on module evaluation forms for both } \\
\text { optional and compulsory modules. }\end{array}$ \\
responses and feedback gathered: 70
\end{tabular}




\section{Analysis}

\section{Experiential learning in practice}

The value of an experiential approach to learning is confirmed by scholarship (Biggs, 2011; Gibbs, 1988; Vyakarnam \& Hartman, 2011). Participants need to work with and apply knowledge in order to achieve deep learning, building on solid foundations of declarative knowledge, to use functioning knowledge to learn experientially and arrive at threshold concepts, where they have new levels of understanding, reflecting on and evaluating outcomes, re-conceptualizing their knowledge, and seeing it in a new light (Angelo, 1993; Biggs \& Tang, 2011). For example, a PGR Development School participant reconceptualised their knowledge and arrived at a new understanding:

I always thought, because of my niche background (philosophy) that I was destined for a life of solitary work and limited opportunity. I learned that I have more to offer than that, and learned the real meaning of transferable skills (PhD student, 2013).

\section{Metacognition and reflective learning}

The significance of active, reflective learning is emphasized in the seminal work of Biggs and Tang as a means of achieving deeper learning and the performance of understanding (Biggs \& Tang, 2011) through working with knowledge towards solving novel problems. They identify that Problem Based Learning (PBL), a form of experiential learning, has scope to support employability, since if students graduate with functioning knowledge, their induction into real life professional practice will be quicker (Biggs \& Tang, 2011, p. 187). The following quote from PGT module feedback contributes to unpacking this:

This module provided the opportunity to push yourself out of your comfort zone and engage with a different form of learning. At first I was incredibly dubious as it seemed very far removed from what I was studying for my degree. However, after the business plan was re-worked from the feedback given I became very excited about both the new business idea and what I was learning from it, at this point I grasped the 'why' learning outcome! (MSc student, 2016).

Using the lens of the USEM framework in the design of appropriate pedagogies and curricula (Knight \& Yorke, 2004) Understanding is addressed by designing and planning the learning and development activities to introduce participants to relevant knowledge and provide opportunities to learn actively and experientially by doing a series of practical activities. Skilful practices, skills understood as situated practices, are applied in the context of the real life project or problem being addressed. Experiential learning through the practical application of knowledge, skills and attributes is a core principle of enterprise education; participants apply the skills, knowledge and attributes needed to apply creative ideas and innovations to practical situations, including initiative, independence, creativity, problem solving, identifying and working on opportunities, leadership, acting resourcefully and responding to challenges (Rae, 2007). This develops Efficacy beliefs and confidence through having the experience, learning by doing and engaging in situated practice (Bandura, 1977, 1997; Vyakarnam \& Hartman, 2011). Metacognition is achieved through reflection on the learning and the process of learning. Reflection is encouraged as a key way of supporting learning in the programmes under consideration, typically prompted by a series of reflective questions drawn from the work of Gibbs (Gibbs, 1988).

It is essential to create an appropriate learning environment when new learning experiences and approaches are to be engaged with, which mean that participants' comfort zones are to be disrupted (Belluigi, 2013; Boler, 1999; Vyakarnam \& Hartman, 2011); an environment which needs to be hospitable, creates a sense of safety and solidarity and offers the possibility for participants to take some responsibility for their own learning:

de Blaquière , G.E., Nolan, J.E., \& Wray, K. (2019). Joining up the dots: telling the story of employability. How can students in Higher Education be supported to better understand and articulate their employability? Journal of Teaching and Learning for Graduate Employability, 10(2), 15-35. 
Throughout the Enterprise programme, I have developed and demonstrated sustainable enterprising skills; to adopt an active and creative approach to problem solving often under minimum supervision (Enterprise programme participant, 2011).

A facilitative approach to delivery is required to support participants both in formal and informal environments, for example making the potentially formal setting of a training session into a more active learning space through small group activities, practicing and experimenting in the safety of the classroom with support before applying the knowledge and skills "for real" in the process, in this case, of researching and developing a hypothetical business or project. This approach invites learners to step outside their comfort zones and to establish relationships and trust through practical hands on interactions. Working with others is noted by participants in their feedback:

Engaging with a team with a wide variety of personalities and science backgrounds is a challenging but rewarding task (Enterprise programme participant, 2011).

To create the scaffolding to help participants engage with enterprise and move into the more uncertain experiential avenues for their learning (Belluigi, 2013) participants are invited to consider the philosophical aspects, their personal values and the capacity of using an enterprising approach and an entrepreneurial mind-set as a way to enable them to enhance impact were explored:

It has really challenged my ideas around the role of research and inspired me both about the value of collaborating across cultures and disciplines, as well as the potential for creating impacts with spin out activities from my research (PGR Development School participant, 2013).

The curriculum should be challenging and the relationships which sustain the learning should be receptive, supportive and dynamic (Belluigi, 2013). Each of the examples under consideration aimed to establish this type of environment and this in turn enabled participants to accept some uncertainty and even anxiety as part of their transformative learning; people were willing to step out of their comfort zones (Belluigi, 2013; Boler, 1999).

Stepping out of your comfort zone and learning, learning, learning (Enterprise programme participant, 2012).

These pedagogical considerations informed the architecture of practice (Kemmis \& MCTaggart, 1982) which has been used in all the interventions under consideration.

\section{Findings}

Analysis of the data is provided in Figures 2 to 5 . The analysis of the comparative PGR Development workshops baseline data found that where experiential workshops are evaluated, the mean agreement scores increase for both the efficacy beliefs (confidence) question and the development of skilful practice question, regardless of the subject content. Figure 2 analyses the confidence levels and skills development in 77 workshops which did not include any experiential element compared to 87 workshops which had an experiential element. A significant increase in mean agreement scores for both areas was demonstrated in the experiential workshops.

de Blaquière , G.E., Nolan, J.E., \& Wray, K. (2019). Joining up the dots: telling the story of employability. How can students in Higher Education be supported to better understand and articulate their employability? Journal of Teaching and Learning for Graduate Employability, 10(2), 15-35. 


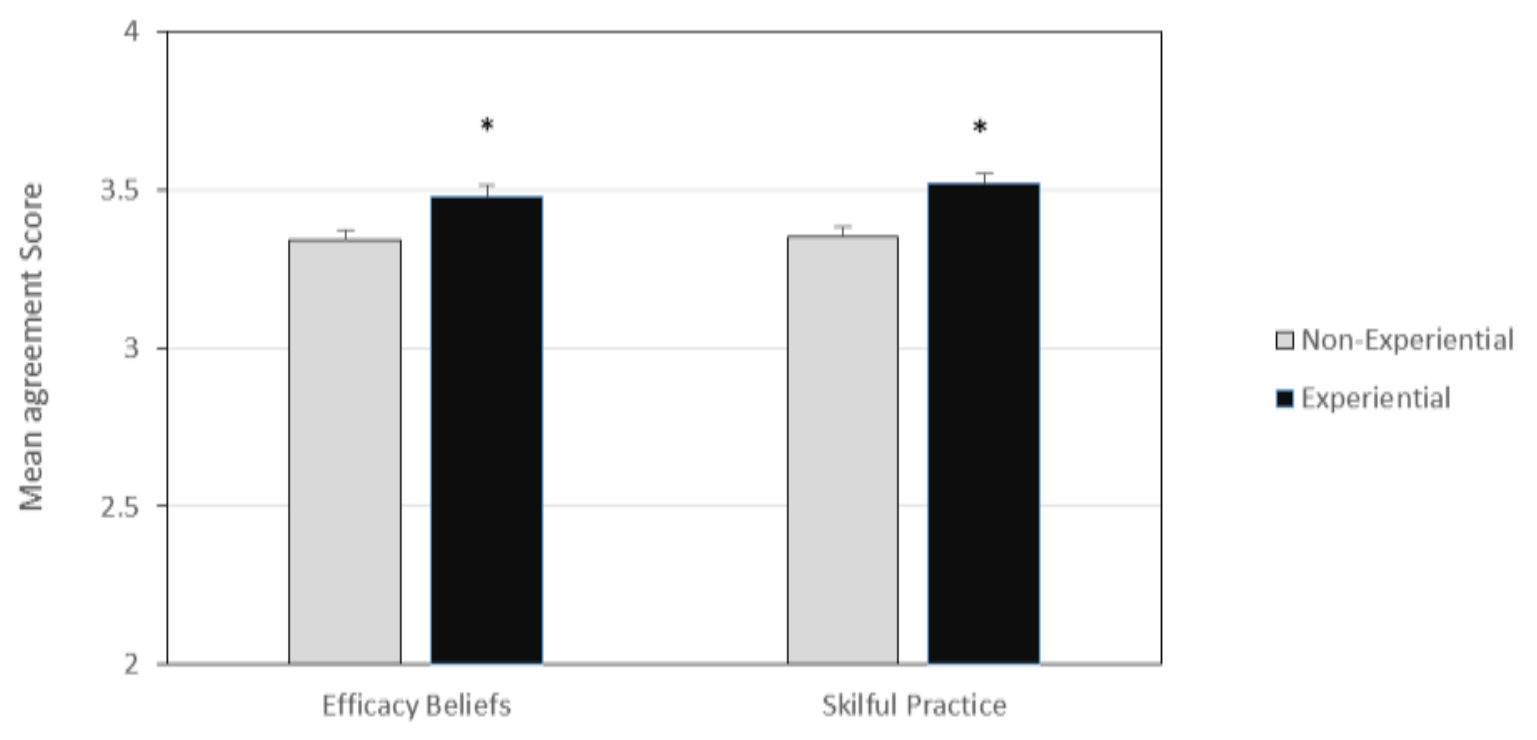

Figure 2: Postgraduate Researcher Development Workshop Series 2015-16

A four point Likert scale was used to score participants' agreement with statements on their efficacy beliefs and skilful practice (with a score of 1 for strongly disagree to 4 representing strongly agree) with the following:

Efficacy Belief: This course has increased my knowledge and/or improved my skills in the relevant RDF sub-domains.

Skilful Practice: The skills learned will improve my transferable/employment skills.

Parametric statistical analysis was then carried out on the responses using 2 sample $t$ tests and results are displayed as mean $+/$ - standard error $(p<0.001)$. Sample size $(n=77$ workshop instances for nonexperiential and $n=87$ for experiential).

Quantitative analysis of more detailed data from the Enterprise programme, PGR Development School and business start-up pre-accelerator project demonstrates that a significant increase in confidence levels and greater understanding of skills can be achieved through experiential interventions. Figures 3 and 4 illustrate this with results for specific questions on communication, group/team work and creativity for the enterprise programme and PGR Development School. This is reinforced by the following qualitative comments from the participants:

Being an enterprise programme participant is learning to utilise resources in the right manner. It is a joy to be able to work with people from different disciplines (Enterprise programme participant, 2012).

...the skills I learned on the PGR Development School helped me to have the confidence to go up and talk to keynote speakers at a conference. As a result I have created contacts which I have been able to use in research interviews and workshops (PGR Development School participant, 2014).

The design of the business start-up pre accelerator project feedback allowed quantitative analysis of the responses on an individual basis, with each person surveyed pre and post programme, compared to the anonymous feedback analysed previously (Figure 5). The mean agreement score with the efficacy belief question increased by $18 \%$ overall post programme. Statistical analysis of the matched pairs using paired $t$-tests showed this was a significant increase $(p<0.05)$. The $9 \%$ increase in the mean agreement score with the efficacy belief question was not statistically significant, possibly due to the small numbers on the programme, but still indicates a gain in awareness post-programme.

de Blaquière , G.E., Nolan, J.E., \& Wray, K. (2019). Joining up the dots: telling the story of employability. How can students in Higher Education be supported to better understand and articulate their employability? Journal of Teaching and Learning for Graduate Employability, 10(2), 15-35. 


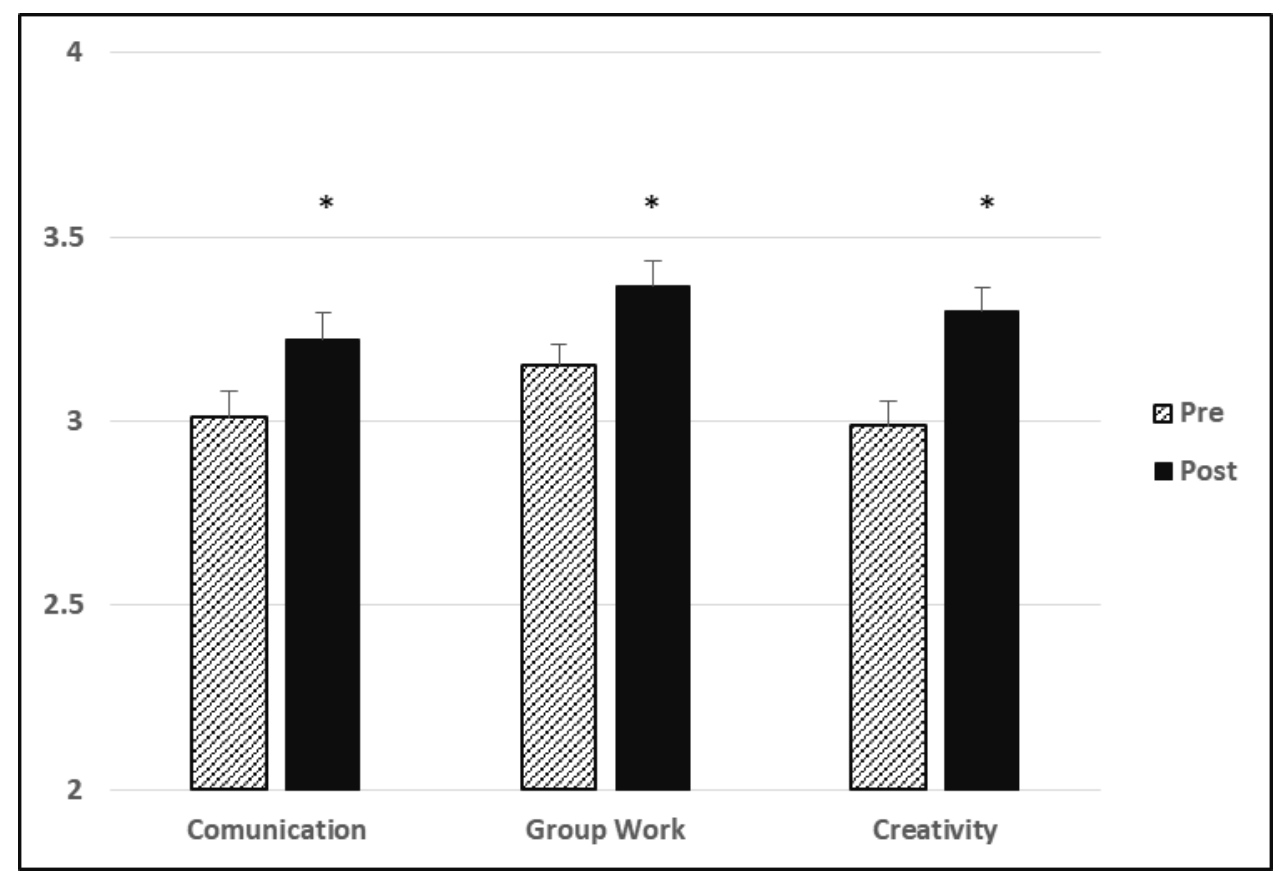

\section{Figure 3: Enterprise Programme}

A Skills Perception Inventory (SKIPI) was carried out prior to the enterprise programme and after the first two day workshop had concluded. The questions in the SKIPI were designed to gauge confidence levels in three skills areas covered in the enterprise programme: Communication, Group work, Creativity and Entrepreneurial.

Researchers were asked to rate their level of confidence with a series of situations or issues. A four point scale was used to score participants' perceptions (with a score of 1 for very uncomfortable to 4 representing very comfortable) for the following:

Efficacy Belief questions: Communication and Group work

Skilful Practice questions: Creativity and Entrepreneurial skills.

Data Reduction: Principle components analysis for each of the question groupings led to solutions with one dominant component confirming that each set of questions act as a consistent measure of a single underlying dimension. Differences between the combined responses for each grouping were measured using ANOVA and results are displayed as mean +/- standard error $(p<0.05$ communication; $p<0.01$ group work; $p<0.001$ creativity). Sample size ( $n=21$ pre-workshop and $n=17$ post-workshop). 


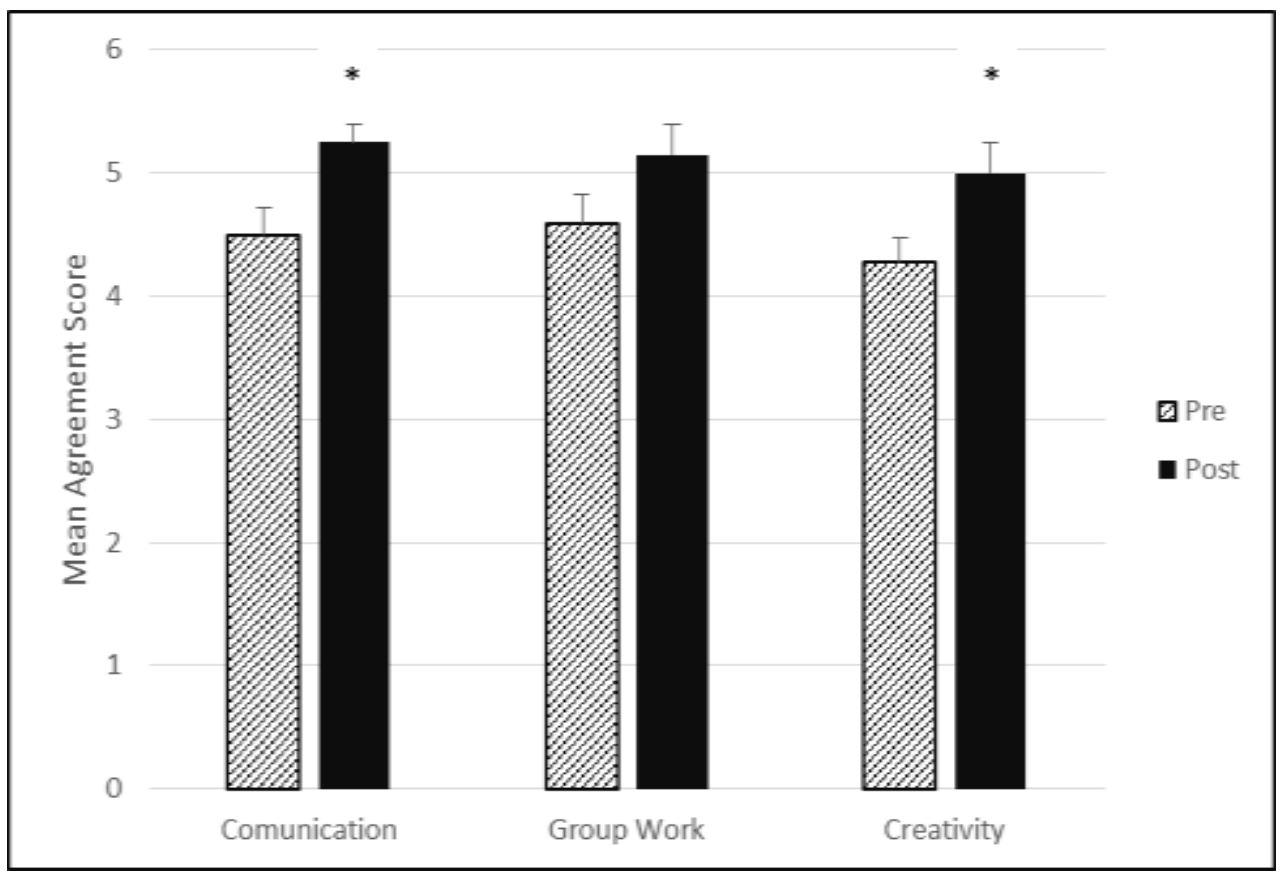

Figure 4: PGR Development School

A Skills Perception Inventory (SKIPI) was carried out prior to the first two week School and just after the second two week School had concluded six months later. Researchers were asked to rate their level of confidence. A six point scale was used to score participants' perceptions (with a score of 1 for not at all confident to 6 representing very confident) on the following:

Efficacy Belief: Communication and Group work

Communication Question: How confident do you feel you can effectively communicate with people in different organisations?

Group work question: Confidence in developing collaborative relationships

Skilful Practice: Creativity and Entrepreneurial skills

Creativity question: How confident do you feel in taking creative and innovative approaches to your work?

Differences between the combined responses for each grouping were measured using 2 sample t-tests and results are displayed as mean $+/$ - standard error $(p<0.006$ communication; $p<0.1$ group work; $p<0.03$ creativity). Sample size ( $n=22$ pre-workshop and $n=20$ post-workshop).

de Blaquière , G.E., Nolan, J.E., \& Wray, K. (2019). Joining up the dots: telling the story of employability. How can students in Higher Education be supported to better understand and articulate their employability? Journal of Teaching and Learning for Graduate Employability, 10(2), 15-35. 


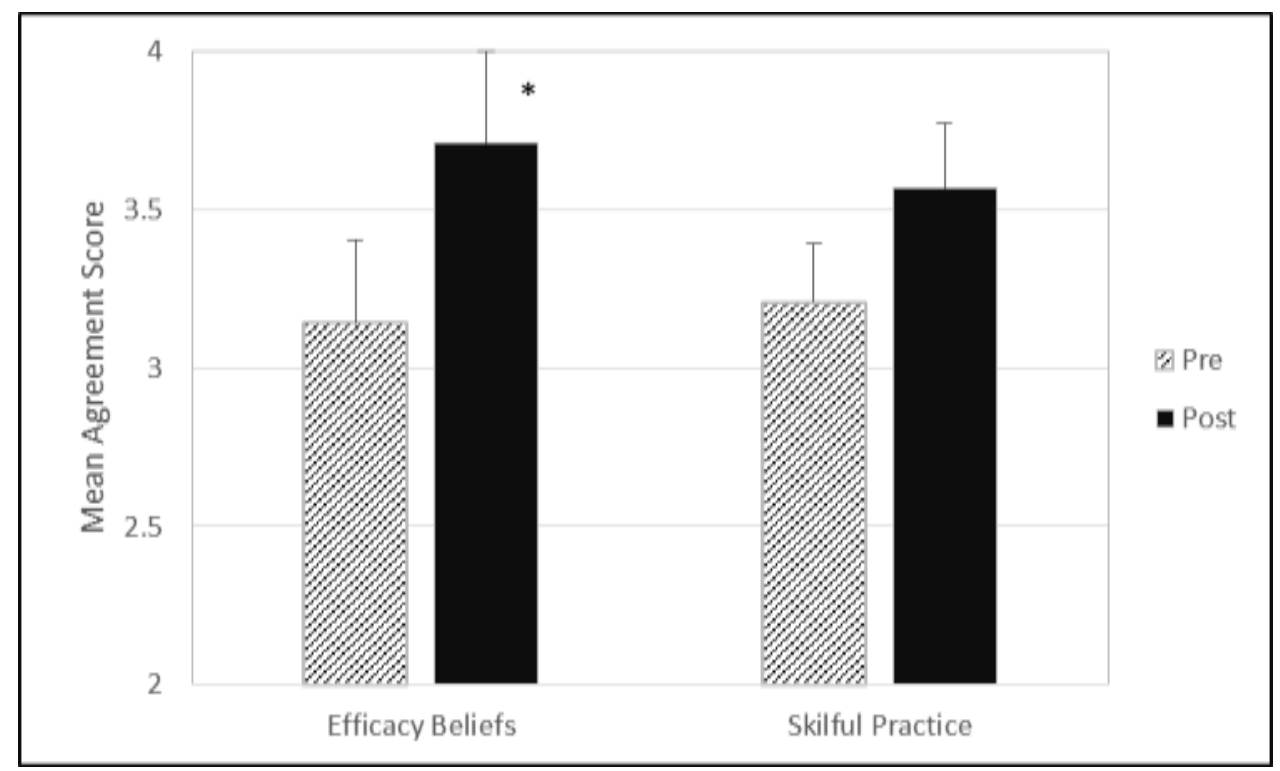

\section{Figure 5: Business Start-Up Pre-Accelerator}

A Skills Perception Inventory (SKIPI) was carried out at the prior to the programme and one month after the programme had concluded. Researchers were asked to rate their level of confidence with a series of situations or issues. A four point scale was used to score participants' perceptions (with a score of 1 for very uncomfortable to 4 representing very comfortable) of the current level of comfort/confidence in the following area:

Efficacy Belief question: Belief in my own ability

Skilful Practice question: Awareness of my strengths

Differences between the combined responses for each grouping were measured using paired t-tests (one tail) and results are displayed as mean $+/$ - standard error $(\mathrm{p}<0.05$ efficacy belief). Sample size $(\mathrm{n}=$ 7).

\section{Discussion}

The above findings suggest that the experiential forms of learning used in the interventions under consideration resulted in greater increases in confidence (efficacy beliefs) and skills awareness (skilful practices) as compared with non-experiential forms of learning. Analysis of both the quantitative data and the rich qualitative feedback has included reflection on the narratives which participants have created following their experiential learning during these interventions, which it is argued, suggests that metacognition has been achieved as a result of their participation in the interventions.

In their reflections, the participants articulate the application of their skills and confidence, giving examples of how their skills have been put into practice. There is evidence of reflection and transformational learning, where people have come to a new understanding of what they can offer in terms of their employability skills. The development of narratives is being encouraged, by raising the level of consciousness of skilful practices through good reflective practice, which can enable participants to achieve metacognition and allowing space for those narratives to speak. This is crucial to validating their identities as employable graduates and provides resources for future job applications and interviews. The data shows that even short interventions can have an impact, though longer interventions relating to a real life challenge provide greater space and opportunity for narrative development.

de Blaquière , G.E., Nolan, J.E., \& Wray, K. (2019). Joining up the dots: telling the story of employability. How can students in Higher Education be supported to better understand and articulate their employability? Journal of Teaching and Learning for Graduate Employability, 10(2), 15-35. 
The narratives quoted in this article are a small sample of an extensive body of data and are considered as representative. Whilst it is acknowledged that these narratives are self-reported and not verifiable, it is significant that the participants are drawing on their perceptions of how their employability skills, such as self-confidence, self-awareness, creativity, entrepreneurialism, commercial awareness, communication and teamwork have increased; their perceptions are important to their sense of identity and of being employable. They also suggest that horizontal learning (Akkerman \& Bakker, 2011) which helps to prepare participants for transitions into the workplace may be occurring.

One attendee at a Postgraduate researcher development workshop which includes experiential learning evidenced their perceptions as follows:

This workshop has provided me with techniques that I have already put into practice and seen an almost immediate beneficial impact on my work. My productivity has more than doubled and I have increased self-confidence as a result (PhD Student, 2016).

An Enterprise programme 2011 participant spoke about their increased commercial awareness:

I have experienced the business-side of scientific research, which is important for all scientists to understand and this is something I can apply to my Doctorate and in my future career.

The feedback from the PGR Development School included much testimony about the huge amount of learning, personal and professional development from it, recognising the tangible benefits created both inside and outside academia, with recognition by the participants that the experience had stretched them and provided transformative learning:

It made me very keen to pursue more collaborative projects because it is remarkable how much these types of projects can push you to your limits and really bring out the best in you (PhD student, 2013).

Drawing on a survey five months after the PGR Development School, in answer to the questions 'What do you think you gained from the experience, as both a researcher and an individual?' and 'Do you have any examples of specific things that you have been able to do or achieved as a result of participating in the programme?' participants responded with extended narratives which indicate their metacognition and reflective learning, for example:

During my job interview, I had to give a 40 minutes presentation. I considered the diverse backgrounds of the researchers and provided an interesting and impactful overview with visually appealing slides to attract the attention of the audience. This has received lot of attention and was helpful in bringing audience engagement. This can be directly attributed to some of the training I got from the School. This experience has encouraged me to think of the cultural differences in student group when I was planning talk for students undertaking a masters module and also to present in a way to encourage discussion. I have become more open towards collaboration and willing to work in different cultures than before (PhD Student, 2014).

I'm helping my supervisor to coordinate an international research project which has collaboration partners from all over the world. I have also taken part in other international research projects/activities as a representative of my research group, department or university. I have been awarded funding for a two-year international collaboration project as a coapplicant, and I'm applying [for] more funding to initiate even more international collaboration projects from various funding bodies. All training and experience from the Enterprise programme help me to handle these jobs much better and more confidently (PhD Student, 2014).

A response from the business start-up pre-accelerator intervention indicates skills learnt for continued development in the future:

de Blaquière, G.E., Nolan, J.E., \& Wray, K. (2019). Joining up the dots: telling the story of employability. How can students in Higher Education be supported to better understand and articulate their employability? Journal of Teaching and Learning for Graduate Employability, 10(2), 15-35. 
It gave us the time, space and support to grow a concept into a prototype business, which we have continued to iterate on. It was the first step on an amazing journey (Graduate, 2016).

Feedback from an UG module has also shown the understanding of the skills actively and experientially applied in context and how they contribute to employability, which involves understanding, reflection and metacognition in order for participants to be able to articulate their skills:

The elements of the Module that have been valuable to me were hearing about the real life experiences of the music industry, when speakers offered advice and shared their experiences; creating, managing and delivering a musical event, and having complete creative control; learning about and actually doing event planning and management, promotion, marketing design, social media, finance and budgeting, negotiation and networking. The presentation assessment was very helpful in gaining skills and experience for presentation planning and design, teamwork and communication.

The module gave the opportunity to develop essential "soft skills" that employers look for, with the vital evidence and experience to support it, including communication, making decisions, showing commitment, flexibility, time management, leadership skills, creative and problem solving skills, being a team player, accepting responsibility and an ability to work under pressure. The module has allowed me to develop the skills needed to gain an internship placement at an Arts venue, where I am using the transferable skills from the module. It also gave me the commercial awareness I needed to achieve my goals within the internship (UG Student, 2015).

\section{Conclusions}

This study has considered data collected from a variety of interventions in a UK Higher Education setting and made comparisons of pre- and post- intervention participant perceptions. It has considered qualitative data provided by participants and has mapped this against a theoretical framework (USEM model) and pedagogical research, in order to achieve the aims of the study. From this analysis of a rich data set from both undergraduate and postgraduate taught and research programmes and modules, across different Schools and through different interventions, the findings of this study have enabled the authors to propose a theoretically-informed practice architecture based on their practitioner experience (Figure 6) which can be applied to curricular, extra-curricular and training development activities.

It is argued that this architecture would facilitate reflection and metacognition, resulting in the understanding and articulation of skills-in-context and the development of new narratives which can evidence employability. This practice architecture provides applied and practical experiential opportunities for disciplinary study, interdisciplinary work (extra and co-curricular) and active learning, working across boundaries such as disciplines, the Academy, communities and business which are likely to challenge the participants through their unfamiliarity, which together can contribute to the horizontal learning which helps to support the transition into the workplace (Akkerman \& Bakker, 2011).

de Blaquière , G.E., Nolan, J.E., \& Wray, K. (2019). Joining up the dots: telling the story of employability. How can students in Higher Education be supported to better understand and articulate their employability? Journal of Teaching and Learning for Graduate Employability, 10(2), 15-35. 


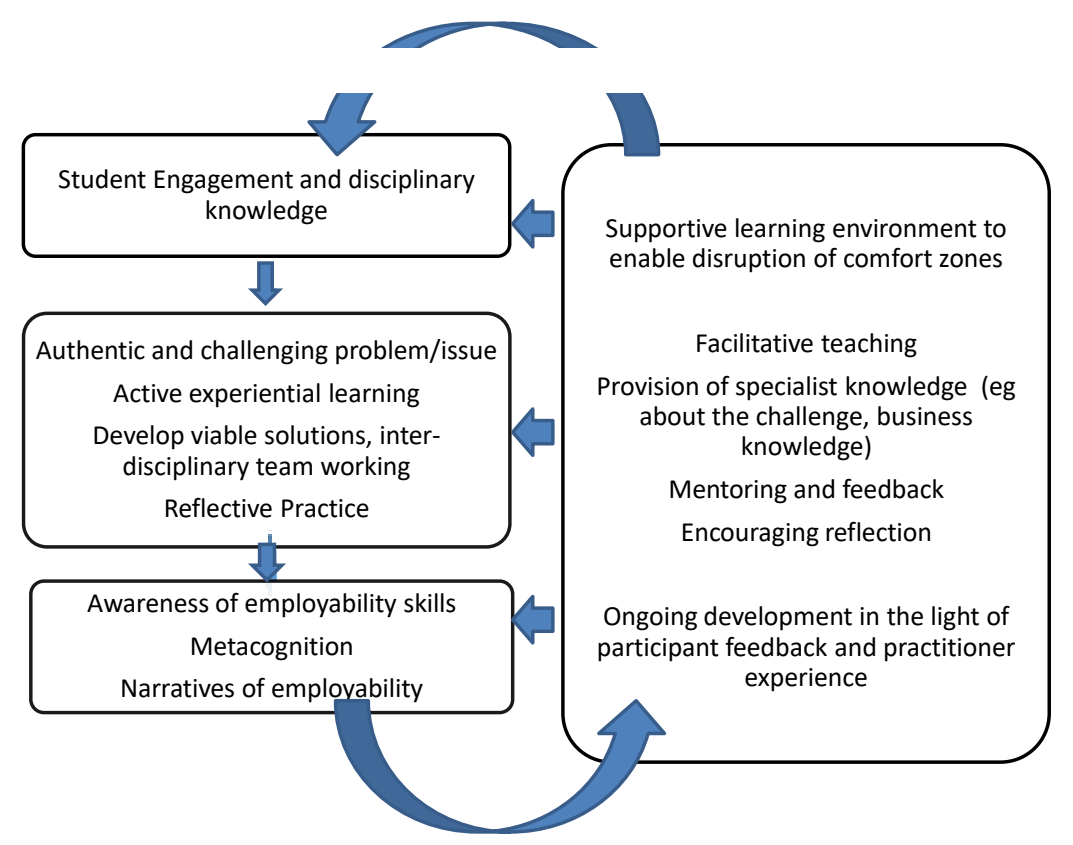

\section{Figure 6: Creating the Practice Architecture}

To apply the practice architecture in Figure 6, practitioners need to create a supportive learning environment which enables participants to step out of their comfort zones and facilitates their independent, active learning. They need to provide any specialist knowledge about the authentic and challenging problem or issue which their participants will address. They also need to provide mentoring, formative feedback and encourage reflection on experience. Participants need to be engaged with the challenging problem or issue, bring their disciplinary knowledge into an inter-disciplinary team and engage in active, experiential learning and work across boundaries such as the academy, business and community, to develop, research and present viable solutions to the problems under consideration. Reflective practice is essential to achieving metacognition; the perception of skills which have been applied and how the experience can be used as examples in coherent narratives of employability, which evidence what the participant can offer. The principles shown in Figure 6 are offered as an architecture that might be used by other practitioners, though these are not seen uncritically or as a black box solution.

A new definition is suggested here for experiential learning as those activities which require participants to become part of a real-life context or challenge, rather than knowledge/information transfer activities which do not 'do' or have a reflection on 'doing". This, along with the reflection inherent and actively encouraged in the learning environment may help participants to learn from and cope with the discontinuities associated with working across boundaries or in new territories in the future, such as the workplace. To work across boundaries, participants encounter different languages, expectations and rules, enabling them to learn through applying skills in context, and in turn develop their confidence, understand their employability skills and articulate them in new narratives.

This study has argued that space is needed within HE programmes of study for metacognition to be achieved, if students and graduates are to understand and articulate their employability. An approach to doing this has been outlined, evidenced by extensive data and with reference to Knight and Yorke's USEM model (Knight \& Yorke, 2004). Participants have been able to achieve metacognition, develop coherent narratives and new constructions of identity as a result of their experiential learning through working across boundaries and responding to real-life challenges, enabling them to 'join up the dots' and tell the story of their employability.

de Blaquière , G.E., Nolan, J.E., \& Wray, K. (2019). Joining up the dots: telling the story of employability. How can students in Higher Education be supported to better understand and articulate their employability? Journal of Teaching and Learning for Graduate Employability, 10(2), 15-35. 
The authors intend to undertake further research and make recommendations based on their research and experience about embedding these architectures of practice into future curricula, including extra-, co- and core curricula, to support the creation of coherent narratives of employability and to help students prepare for their transition into life after graduation.

\section{Acknowledgement}

This research received no specific grant from any funding agency in the public, commercial, or not-forprofit sectors. The authors would like to thank the Equate team at Newcastle University for their encouragement, guidance and the opportunity to undertake this research project, and the inaugural International Researcher Development School project team for permission to use project data.

\section{References}

Akkerman, S. F., \& Bakker, A. (2011). Boundary crossing and boundary objects. Review of Educational Research, 81(2), 132-169. doi: 10.3102/0034654311404435

Akkerman, S. F., \& Van Eijck, M. (2013). Re-theorising the student dialogically across and between boundaries of multiple communities. British Educational Research Journal, 39(1), 60-72. doi: 10.1080/01411926.2011.613454

Alpay, E., \& Walsh, E. (2008). A skills perception inventory for evaluating postgraduate transferable skills development. Assessment and Evaluation in Higher Education, 33(6), 581-598. doi: 10.1080/02602930701772804

Angelo, T. A. (1993). A 'Teacher's Dozen': Fourteen general, research-based guidelines to inform college teaching and assessment and improve higher learning. Paper presented at the American Association for Higher Education.[retrieved 22 Apr 2004, verified 29 Jan 2005] http://www. princeton. edu/ aiteachs/workshop/14. html.

Bandura, A. (1977). Self-efficacy: Toward a unifying theory of behavioral change. Psychological review, 84(2), 191-215.

Bandura, A. (1997). The exercise of control. New York: Freeman.

Bathmaker, A. M., Ingram, N., \& Waller, R. (2013). Higher education, social class and the mobilisation of capitals: Recognising and playing the game. British Journal of Sociology of Education, 34(5-6), 723-743. doi: 10.1080/01425692.2013.816041

Becker, G. S. (1975). Human Capital. Chicago: University of Chicago Press.

Belluigi, D. Z. (2013). A proposed schema for the conditions of creativity in fine art studio practice. International Journal of Education \& the Arts, 14(19), 1-23.

Biggs, J. B. (2011). Teaching for quality learning at university: What the student does: UK: McGraw-Hill Education.

Biggs, J. B., \& Tang, C. S. (2011). Teaching for quality learning at university: UK: McGraw-Hill Education.

Boler, M. (1999). Feeling power: Emotions and education: Psychology Press.

Brown, P., Hesketh, A., \& Williams, S. (2004). The mismanagement of talent: Employability and jobs in the knowledge economy: Oxford: Oxford University Press.

Bryant, R. A. (2005). But I have no skills. Chronicle of Higher Education.

Bryman, A. (2008). Social research methods (3rd ed.). Oxford: Oxford University Press.

Creswell, J. W. (2014). Research design: Qualitative, quantitative, and mixed methods approaches. (4th ed.). Thousand Oaks, California: SAGE Publications.

Eva-Sys. Eva-Sys Education Survey Automation Suite. Retrieved 24.07, 2017, from http://www.evasys.co.uk/start.html

French, S. (2015). The benefits and challenges of modular higher education curricula. Issues and Ideas Paper. Melbourne: Melbourne Centre for the Study of Higher Education.

de Blaquière , G.E., Nolan, J.E., \& Wray, K. (2019). Joining up the dots: telling the story of employability. How can students in Higher Education be supported to better understand and articulate their employability? Journal of Teaching and Learning for Graduate Employability, 10(2), 15-35. 
Gibbs, G. (1988). Learning by doing: A guide to teaching and learning methods: Oxford Centre for Staff and Learning Development, Oxford Brookes University.

Hacker, D. J., Dunlosky, J., \& Graesser, A. C. (1998). Metacognition in educational theory and practice. New York: Routledge.

Harvey, L. (2000). New realities: The relationship between higher education and employment. Tertiary Education \& Management, 6(1), 3-17.

HEA. (2015). HEA UK Experience Survey. from https://www.heacademy.ac.uk/system/files/ukes 2015.pdf

Holmes, L. (2013). Competing perspectives on graduate employability: Possession, position or process? Studies in Higher Education, 38(4), 538-554.

Holmes, L. (2015). Becoming a graduate: The warranting of an emergent identity. Education+ Training, 57(2), 219-238.

Holmes, L. (2017). Graduate employability: Future directions and debate In M. Tomlinson \& L. Holmes (Eds), Graduate employability in context: Theory, research and debate (pp. 359-369). London: Palgrave Macmillan.

Kemmis, S., \& McTaggart, R. (1982). The action research planner (2nd edn).Victoria, Deakin University.

Knight, P., \& Yorke, M. (2004). Learning, curriculum and employability in higher education: Psychology Press.

Lawler, S. (2002). Narrative in social research. In T. May (Ed.), Qualitative research in action, (pp. 242-258). London: Sage

Lawler, S. (2014). Identity: Sociological Perspectives: London: John Wiley \& Sons.

Marzano, R. J. (1998). A theory-based meta-analysis of research on instruction. Colorado: Office of Educational Research and Improvement.

Mok, K. H., \& Wu, A. M. (2016). Higher education, changing labour market and social mobility in the era of massification in China. Journal of Education and Work, 29(1), 77-97. doi: $10.1080 / 13639080.2015 .1049028$

Morley, L. (2007). The X factor: employability, elitism and equity in graduate recruitment. Twenty-First Century Society, 2(2), 191-207. doi: 10.1080/17450140701325782

Nolan, J. (2018). Narrating employability from English, (provisional title). Ongoing Doctoral Research Project. Newcastle University.

Polkinghorne, D. E. (1988). SUNY series in philosophy of the social sciences. Narrative knowing and the human sciences. Albany, NY, US: State University of New York Press.

QAA. (2018). Enterprise and entrepreneurship education: Guidance for UK higher education providers. Retrieved 31.01.18, from http://www.qaa.ac.uk/publications/information-andguidance/publication/?PubID=3222\#.WnHn2Pm6-Uk

Rae, D. (2007). Connecting enterprise and graduate employability: Challenges to the higher education culture and curriculum?, Education + Training, 49(8/9), 605-619

Reay, D. (1998). 'Always knowing' and 'never being sure': Familial and institutional habituses and higher education choice. Journal of Education Policy, 13(4), 519-529. doi: 10.1080/0268093980130405

Reay, D. (2013). Social mobility, a panacea for austere times: Tales of emperors, frogs, and tadpoles. British Journal of Sociology of Education, 34(5-6), 660-677. doi: 10.1080/01425692.2013.816035

Reeves, J., Denicolo, P., Metcalfe, J., \& Roberts, J. (2012). The vitae researcher development framework and researcher development statement: Methodology and validation report. Vitae, Cambridge, 4-10.

Rogers, C. E. (1969). Freedom to learn. Columbus, Ohio: Merrill Publishing Company.

Simon Fraser University. (2012). Retrieved 10.11.17, from https://www.sfu.ca/tlc/blog/Experientialeducation-at-SFU-wide-but-not-deep.html

Tomlinson, M. (2007). Graduate employability and student attitudes and orientations to the labour market. Journal of Education and Work, 20(4), 285-304. doi: 10.1080/13639080701650164

Universities UK, \& CBI. Future fit: Preparing graduates for the world of work. Retrieved 31.01.18, from http://www.universitiesuk.ac.uk/policy-and-analysis/reports/Pages/future-fit-preparing-graduates-forthe-world-of-work.aspx

Vyakarnam, S., \& Hartman, N. (2011). Unlocking the enterpriser inside!: A book of why, what and how! : World Scientific.

Wenger, E. (1998). Communities of practice: Learning, meaning, and identity: UK:Cambridge University Press.

de Blaquière , G.E., Nolan, J.E., \& Wray, K. (2019). Joining up the dots: telling the story of employability. How can students in Higher Education be supported to better understand and articulate their employability? Journal of Teaching and Learning for Graduate Employability, 10(2), 15-35. 
Yin, R. K. (2003). Case study research: Design and methods. SAGE Publications.

Yorke, M. (2006). Employability in higher education: what it is, what it is not. York: Higher Education Academy. 